\title{
Journal of Vacation Marketing
}

http://jvm.sagepub.com

\section{A framework for increasing understanding of self-drive tourism markets \\ Bruce Prideaux and Dean Carson \\ Journal of Vacation Marketing 2003; $9 ; 307$ \\ DOI: $10.1177 / 135676670300900401$}

The online version of this article can be found at:

http://jvm.sagepub.com/cgi/content/abstract/9/4/307

\author{
Published by: \\ (-)SAGE \\ http://www.sagepublications.com
}

Additional services and information for Journal of Vacation Marketing can be found at:

Email Alerts: http://jvm.sagepub.com/cgi/alerts

Subscriptions: http://jvm.sagepub.com/subscriptions

Reprints: http://www.sagepub.com/journalsReprints.nav

Permissions: http://www.sagepub.co.uk/journalsPermissions.nav

Citations http://jvm.sagepub.com/cgi/content/refs/9/4/307 


\title{
A framework for increasing understanding of self-drive tourism markets
}

\author{
Bruce Prideaux* and Dean Carson** \\ Received (in revised form): 30th June, 2003 \\ Anonymously refereed paper
}

* School of Tourism and Leisure Management, University of Queensland, 12 Salisbury Road, Ipswich,

Queensland 4305, Australia

Tel: +61 73381 1008; Fax: +61 73381 1012; E-mail: b.prideaux@uq.edu.au

**Centre for Regional Tourism Research, School of Tourism and Hospitality Management, Southern

Cross University, PO Box 157, Lismore, New South Wales 2480, Australia

Tel: +61 26620 3785; Fax: +61 26620 3565; E-mail: dcarson@ @cu.edu.au

Bruce Prideaux is a senior lecturer in the School of Tourism and Leisure Management at the University of Queensland.

Dean Carson is the Head of the Centre for Regional Tourism Research, Southern Cross University. His research interests include managing regional tourism for economic and social gains, and the use of information and communications technology in tourism product distribution.

\section{ABSTRACT}

KEYWORDS: transport choices, size of drive tourism market, drive market characteristics, case study framework

This paper aims to identify a framework for analysis of case study research into self-drive tourism and its associated markets. The history and significance of drive tourism markets around the world are briefly identified, and statistics are provided to support increased attention being paid to these markets. The lack of existing research is identified, with significant recent exceptions being this special issue of the Journal of Vacation Marketing and a collection of articles edited as a book by Carson et al. ${ }^{1}$ In order to gain greater understanding of the diversity of self-drive tourism markets and their behaviour in destinations, the framework for analysis suggests attention be paid to location (destination) description; visitor characteristics; access, including distance aspects; nature of visitor flows; expenditure patterns; attractions; accommodation; promotion; history; investment; physical infrastructure; cooperation between stakeholders; level of public sector involvement; and economic impacts and innovation.

\section{INTRODUCTION}

The inauguration of the first regular rail passenger services in 1825 by the Stockton and Darlington Railway Company in the UK opened up large parts of the countryside to mass travel. Henry Ford's innovative mass automobile production techniques continued the land transport revolution, enabling travellers to go to those places still inaccessible by rail and freeing land travellers from the constraints of railway timetables and limited network options. Later, air travel was to complete the travel revolution, allowing humanity to visit almost any part of the globe. While air travel superseded rail and road travel in the long-haul sector, the car has become the preferred mode of transport for short-distance travel in many developed countries. The tourism industry has benefited enormously from the car's ability to provide almost unrestricted land travel and in developed nations a significant proportion
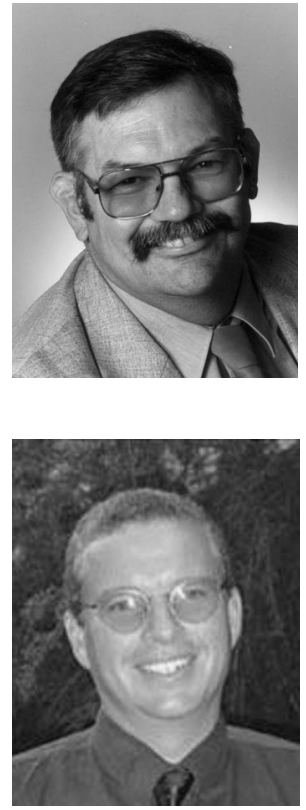

Journal of Vacation Marketing Vol. 9 No. 4, 2003, pp. 307-313, c) Henry Stewart Publications, 1356-7667 
of domestic travellers utilise cars as their main form of holiday transport. In Australia, for example, the Bureau of Tourism Research $^{2}$ reported that 70 per cent of all trips are undertaken by car. The tourism industry has responded to this preference for car travel by developing new forms of accommodation, typified by caravan parks and motels, and investing in tourism attractions located away from major urban centres. Governments have also invested considerable funds in building and maintaining roads and associated infrastructure, funding non-urban attractions and supporting promotional activities by a range of destination marketing organisations (DMOs), state tourism offices (STOs) and regional tourism associations (RTAs).

Until recently, researchers have paid relatively little attention to drive tourism research. This is surprising given the significance of the drive tourism sector in terms of its size, its popularity, the resources allocated to drive tourism infrastructure and its impact on regional tourism. In recent research Carson et al. ${ }^{3}$ edited a timely collection of chapters on a range of drive tourism issues in Australia, and in the most recent initiative the Journal of Vacation Marketing devotes this special issue to the topic. In the future, and as the popularity of drive tourism continues to grow, there will need to be ongoing research in this field.

This paper aims to draw together many of the major issues relating to drive tourism outlined in this special issue and suggest possible future research agendas. One aspect of current research is the extensive use made of case studies as an analytical tool for drive tourism research. For example, in Carson et al. ${ }^{4}$ two-thirds of the contributed chapters utilised case studies as a major or even primary research methodology. A similar observation can be made about this special issue of the Journal of Vacation Marketing, where virtually all papers utilised case studies. Unfortunately the lack of conventions governing the use of case studies as an analytical tool precludes potentially useful comparison between case studies. To redress this deficiency in the literature this paper will suggest a simple analytical framework that may be employed as a method for comparing aspects of drive tourism.

\section{LITERATURE REVIEW}

Many of the recent published papers reporting on drive tourism issues have focused on drive tourism routes or regions attracting drive tourists, ${ }^{5}$ while a second group of papers have focused on the consumers of drive tourism experiences and market segments. ${ }^{6}$ Researchers have focused on a diversity of issues including policy, ${ }^{7}$ the role of drive tourism in regional development, ${ }^{8}$ consumer aspects, ${ }^{9}$ signage, ${ }^{10}$ economic aspects $^{11}$ and safety. ${ }^{12}$

Other studies have focused on issues that affect drive tourism, including the value of travel time, ${ }^{13}$ mode characteristics, ${ }^{14}$ estimates of consumer surplus ${ }^{15}$ and the opportunity cost of various modes of transport. ${ }^{16}$ The measurement of travel characteristics and their effect on travel decisions have been reported by Coto-Millan et al., ${ }^{17}$ Hensher $^{18}$ and Mayeres et al. ${ }^{19}$ There are also a number of unpublished reports, including some identified by Olsen ${ }^{20}$ that have also reported on aspects of drive tourism.

\section{CHARACTERISTICS OF DRIVE TOURISM}

It is useful to re-examine the definitions and major characteristics of drive tourism suggested in the literature. For example, Prideaux et al. ${ }^{21}$ described drive tourism in a broad interpretation as 'tourism that centres on travelling from an origin point to a destination by car that is either privately owned or rented, and engaging in tourismrelated activities during the journey'. More recently, Olsen ${ }^{22}$ added a time element, defining drive tourism as 'Travelling away from home for at least one night, on holidays or visiting friends and relatives, in their own, a rented or borrowed vehicle as the primary mode of transport.' Olsen further narrowed this view of drive tourism by suggesting that drive tourists do not represent a 
homogeneous group of people, although they do share some common characteristics.

In an unpublished report written for Tourism Queensland (TQ) by consultants Yann Campbell Hoare Wheeler ${ }^{23}$ three segments based on travel behaviour were identified. The first segment described drive tourists who stopped where they pleased and was classed as 'a touring segment'. Tourists who break the journey at some point were described as the 'A to B with stops segment', while the final category of tourists who drive to their destination without stopping were classed as the 'A to B segment'. Carr ${ }^{24}$ observed that 'people take drive holidays to capture a sense of freedom or independence, and regard themselves as "travellers" rather than "tourists".' Other characteristics included length of stay away from home, ${ }^{25}$ the infrastructure that services the drive tourism industry ${ }^{26}$ and the structure of iconic routes (as discussed by Anne Hardy in this issue of $J V M)$.

A major aspect of drive tourism is its individuality and lack of rigidity compared to the conformity of a package tour. Compared to a typical mass tourism product a traveller on a drive tour is not necessarily confined by location, selection of activity or timetables. It is the freedom of drive tourists to make and change their itinerary that is a distinguishing factor of drive tourism. Moreover, participants in drive tourism have a greater selection of localities and can decide on the time allocated to specific activities as well as selecting and substituting attractions.

Drive tours and drive tourism can also be differentiated by a range of factors, including the activity engaged in, the itinerary (structure, unstructured), the type of vehicle (conventional, off-road), accommodation type used (motel, camping, caravanning, bed and breakfast), length of time away from home, length of journey, types of activities and attractions visited and age of participants.

\section{THE SIGNIFICANCE OF DRIVE TOURISM}

Carson and Waller $^{27}$ reported on the significance of self-drive forms of transport for domestic and international visitors to Australia. In particular, they emphasised the role self-drive tourism plays in visitation to regional areas, where alternative transport options may be limited. For international visitors to Australia in 1999, over 50 per cent who visited at least one regional centre used self-drive modes of transport at some point in their journey, compared with 40 per cent of those who did not visit regional Australia. For domestic tourists, the rates were 86 per cent and 62 per cent respectively. Importantly, irrespective of destination, self-drive transport was the most common transport item for all visitors to Australia.

In this special issue of Journal of Vacation Marketing, Lori Pennington-Gray identifies similar rates of self-drive tourism for visitors to the USA. The World Tourism Organisation $^{28}$ described the predominance of air and self-drive transport internationally. In 1998 air transport represented 43 per cent of all transport choices for international tourists worldwide, while self-drive accounted for 42 per cent of transport choices. Air transport was more popular in Africa, the Americas and Asia, while selfdrive transport was more popular in Europe, the Middle East and Australasia. Over three-quarters of international visitors to Austria arrive at their main destination by $\mathrm{car}^{29}$ over half of international visitors to Switzerland..$^{30}$ Fewer statistics are available for domestic tourists, but given the experiences of Australia ${ }^{31}$ and the USA it would be expected that self-drive transport is far more common than air transport for domestic tourists internationally. Many of the statistical sources indicate that self-drive tourism is more popular where there are multiple overnight destinations and a longer length of stay. ${ }^{32}$

While there are many international agreements and policy and research institutes relating to air transport, ${ }^{33}$ the development of services for self-drive tourists appears to have been more ad hoc and undertaken with less understanding of how self-drive tourists behave and the differences between self-drive segments. ${ }^{34}$ This is a major deficiency in the 
literature given the economic size of drive tourism, its employment potential and the role of drive tourism in regional economic development.

\section{DEVELOPING AN ANALYTICAL FRAMEWORK}

From the foregoing discussion it is apparent that there are numerous factors which affect and are affected by drive tourism. It is clear that self-drive tourism is different from other forms of tourism, as described in Table $1 .{ }^{35}$ The differences make it harder to track visitors and monitor the performance of selfdrive touring routes and consumer-selected itineraries over time.

To date most research has focused on specific drive tourism issues, specific forms of drive tourism or case studies highlighting specific aspects of drive tourism. As a consequence there has been little opportunity for comparison between factors and localities either locally, regionally or nationally. Drawing on previous research as well as field observation this paper proposes an analytical framework of drive tourism that has sufficient flexibility to be used as the basis for case study research both on a comparative basis between individual or groups of factors and longitudinally over time. Table 2 draws on existing research and author observations to develop an analytical framework that places principal characteristics on the left and factors which impact on these characteristics on the right. Case studies can utilise individual, some or all of these characteristics and

\section{Table 1: Generic characteristics of transport modes}

Mode Characteristics

Road (private car, rental/hire car, taxi, bicycle, foot/other self-propelled, bus/coach)

Rail

Sea (cruise, ferry, private craft)
Relatively slow

Small carrying capacity

Generally high comfort

Flexible itinerary (excluding bus/coach)

Variety of distances

Relatively low cost

Relatively poor safety

Relatively slow

Large carrying capacity

Variable comfort

Rigid itinerary

Variety of distances

Relatively low cost

High safety

Slow

Variable carrying capacity

Relative comfort

Variety of itinerary options

Variety of distances

Relatively high cost

Relatively high safety

Air

Fast

Large carrying capacity

Limited comfort

Rigid itinerary

Longer distances

High cost

High safety 
factors to compare between case studies in any sequence of characteristics. In many cases there will be a degree of overlap between characteristics as well as between factors. Public and private sector factors are one example where this may apply for a number of characteristics, including investment, stakeholders and promotion. Moreover, the list of factors is comprehensive but not exhaustive.

The contributions to this special issue of the Journal of Vacation Marketing can be reviewed against elements of the framework. All papers consider location and visitor characteristics. Anne Hardy is primarily concerned with history, visitor flows and promotion. Both Mark Olsen and Andrew Sivijs look at the historical development of themed touring routes in Queensland, Aus- tralia, and consider investment, infrastructure and economic impacts. Specific visitor characteristics and comparative economic impacts feature in the paper by Lori Pennington-Gray. Eric Laws and Noel Scott are concerned with the role of attractions, implications for infrastructure and public sector involvement (through both investment and resource management). Kevin Shanahan examines accommodation and begins to link physical infrastructure and promotion to the nature of visitor flows.

\section{CONCLUSIONS}

It is apparent that there is considerable scope for future research into drive tourism based on its potential economic impact, particularly in rural and regional settings, the size of

\section{Table 2: A comparative drive tourism framework}

\begin{tabular}{|c|c|}
\hline Characteristic & Factors \\
\hline Location description & $\begin{array}{l}\text { Urban area, rural area, themed route, site, } \\
\text { attractions }\end{array}$ \\
\hline Visitor characteristics & $\begin{array}{l}\text { Number, length of stay, spending, market } \\
\text { segments, age, income }\end{array}$ \\
\hline Access, including distance aspects & $\begin{array}{l}\text { Close to city, affected by peripheral location, moda } \\
\text { characteristic, travel times }\end{array}$ \\
\hline Nature of visitor flows & $\begin{array}{l}\text { Specific routes selected by visitors for accessing } \\
\text { destinations, and for travelling between } \\
\text { destinations }\end{array}$ \\
\hline Expenditure patterns & Products and services accessed by self-drive visitors \\
\hline Attractions & $\begin{array}{l}\text { Ownership, types, opening hours, natural/built, } \\
\text { heritage/cultural }\end{array}$ \\
\hline Accommodation & $\begin{array}{l}\text { Caravan parks, motels, hotels, spas, camping, bed } \\
\text { and breakfast }\end{array}$ \\
\hline Promotion & $\begin{array}{l}\text { Forms such as themed routes, public versus private } \\
\text { sector sponsorship, mass media }\end{array}$ \\
\hline History & $\begin{array}{l}\text { When drive tourists first attracted, history of the } \\
\text { sites visited by tourists }\end{array}$ \\
\hline Investment & Private sector, public sector \\
\hline Physical infrastructure & $\begin{array}{l}\text { Roads, communications, shopping, vehicle repair, } \\
\text { accommodation }\end{array}$ \\
\hline Cooperation between stakeholders & $\begin{array}{l}\text { Between stakeholders in a specific region, between } \\
\text { regions, between public and private sectors, } \\
\text { including product and destination linkages }\end{array}$ \\
\hline Level of public sector involvement & $\begin{array}{l}\text { Which level of the public sector (local, state, } \\
\text { national), type of involvement, including } \\
\text { regulations, investment and subsidies }\end{array}$ \\
\hline Economic impacts and innovation & $\begin{array}{l}\text { Job generation, new businesses, clustering and } \\
\text { networks }\end{array}$ \\
\hline
\end{tabular}


the market and the potential for the emergence of new markets. Of particular interest for stakeholders involved in designing, promoting and administering elements of the drive tourism experience are studies comparing initiatives such as themed routes and economic impacts. An appropriately modified version of Table 2 would be an ideal tool for studies of this nature, so that specific components of self-drive tourism case studies could be catalogued against elements of the framework and compared accordingly.

Given the continuing significance of selfdrive modes of transport for tourism internationally, and the apparent fragility of air transport following the war on terror and related events, it is likely that tourism marketers will look to implement strategies to compete for greater shares of self-drive visitors. This will have implications for the placement of product information (including potential changes in the use of visitor services); the development of signage and themed touring routes; the expectations of visitor behaviour (perhaps involving longer length of stay but with different expenditure patterns); and the development of infrastructure. Research such as reported in Carson et al. ${ }^{36}$ and in this Journal of Vacation Marketing special issue offers some insights into how marketers and destination managers may approach this work. Increased understanding of the dynamics of self-drive tourism will emerge from application of the analytical framework proposed in this paper. Case studies are important for developing this framework, but there is the need to conduct more concerted data analysis involving multiple destinations and empirical data sources.

\section{REFERENCES}

(1) Carson, D., Waller, I. and Scott, N. (eds) (2002) 'Drive Tourism: Up the Wall and Around the Bend', Common Ground Publishing, Melbourne.

(2) Bureau of Tourism Research (2000) 'National Visitors Survey', Bureau of Tourism Research, Canberra.

(3) Carson et al., ref. 1 above.

(4) Ibid.
(5) Ware, C. and Budge, S. (2002) 'The great green way', in Carson et al., ref. 1 above, pp. 63-68; Sproule, R. (2002) 'Cluster marketing in Tasmania', in Carson et al., ref. 1 above, pp. 53-62.

(6) Vincent, V. C. and Santos, G. (1990) 'Winter Texans: Segments of the senior travel market', Journal of Travel Research, Summer, pp. 9-12; Prideaux, B., Wei, S. and Ruys, H. (2001) 'The senior drive tour market in Australia', Journal of Vacation Marketing, Vol. 7, No. 3, pp. 209-219; Stewart, W. P., Lue, C. C., Fesenmaier, D. R. and Anderson, B. S. (1990) 'A comparison between welcome centre visitors and general highway auto travellers', Journal of Travel Research, Winter, pp. 40-46; Prideaux, B. (2002) 'Senior drive tourism in Australia', in Carson et al., ref. 1 above, pp. 33-40; Derrett, R. (2002) 'Drive tourism and special interest tourism', in Carson et al., ref. 1 above, pp. 25-32; Scott, N. (2002) 'Product market perspective of self-drive tourism', in Carson et al., ref. 1 above, pp. 81-90.

(7) Prideaux, ibid.

(8) Roehl, W. S., Fesenmaier, J. and Fesenmaier, D. R. (1993) 'Highway accessibility and regional tourism expenditure', Journal of Travel Research, Winter, pp. 58-63; Carson, D. and Waller, I. (2002) 'The nature of drive tourism in Australia', in Carson et al., ref. 1 above, pp. $1-10$.

(9) Derrett, ref. 6 above.

(10) Dornbusch, D. M. and Kawczynska, C. J. (1992) 'Tourist oriented directional signs: A self-supporting program to promote rural business and economic development', Journal of Travel Research, Summer, pp. 3-9.

(11) Greffe, X. (1994) 'Is rural tourism a lever for economic and social development?', Journal of Sustainable Tourism, Vol. 2, Nos 1-2, pp. 22-44; Prideaux, B. (2000) 'The role of the transport system in destination development', Tourism Management, Vol. 21, pp. 53-63.

(12) Wilks, J., Watson, B. and Hansen, J. (2000) 'International drivers and road safety in Queensland, Australia', Journal of Tourism Studies, Vol. 11, No. 2, pp. 36-43.

(13) Ankomah, P. K. and Crompton, J. L. (1992) 'Tourism cognitive distance: A set of research propositions', Annals of Tourism Research, Vol. 19, pp. 323-342; Cherlow, J. R. (1981) 'Measuring values of travel 
time savings', Journal of Consumer Research, Vol. 7, pp. 360-371; Chevs, J. R., Stoll, J. and Sellar, C. (1989) 'On the commodity value of time travel in recreational activities', Applied Economics, Vol. 21, pp. 711722; Walsh, R. G., Sanders, L. D. and McKean, J. R. (1990) 'The consumption value of travel time on recreation trips', Journal of Travel Research, Vol. 24, No. 1, pp. 17-24.

(14) Barff, R., Mackay, D. and Olshavsky, R. W. (1982) 'A selective review of travelmode choice models', Journal of Consumer Research, Vol. 8, pp. 370-380.

(15) Walsh et al., ref. 13 above.

(16) Morrison, S. A. and Winston, C. (1985) 'An economic analysis of the demand for intercity passenger transportation', in Keeler, T. E. (ed.) 'Research in Transportation Economics: A Research Annual', JAI Press, Greenwich, pp. 213-237.

(17) Coto-Millan, P., Banos-Pino, J. and Inglada, V. (1997) 'Marshallian demands of intercity passenger transport in Spain: 19801992. An economic analysis', Transportation Research Part E: Logistics and Transportation Review, Vol. 33, No. 2, pp. 79-96.

(18) Hensher, D. (1993) 'The transportation sector in Australia: Economic issues and challenges', Transportation Policy, Vol. 1, No. 1, pp. 49-67.

(19) Mayeres, I., Ochelen, S. and Proost, S. (1996) 'The marginal external cost of public transport', Transportation Research Part D: Transport and Environment, Vol. 11, No. 2, pp. 111-130.

(20) Olsen, M. (2002) 'Keeping track of the selfdrive market', in Carson et al., ref. 1 above, pp. $11-24$.
(21) Prideaux et al., ref. 6 above.

(22) Olsen, ref. 20 above, p. 18.

(23) Yann Campbell Hoare Wheeler (1999) 'Road Travellers Study - Research Report', Tourism Queensland, Brisbane.

(24) Hardy, A. (2003) 'An investigation into the key factors necessary for the development of iconic touring routes', Journal of Vacation Marketing, Vol. 9, No. 4, pp. 314-330.

(25) Yann Campbell Hoare Wheeler, ref. 23 above.

(26) Prideaux, B. (2000) 'The role of the transport system in destination development', Tourism Management, Vol. 21, pp. 53-63.

(27) Carson and Waller, ref. 8 above.

(28) World Tourism Organisation (2000) 'Tourism Market Trends', available at www. world-tourism.org/, accessed 6th June, 2003.

(29) Austrian National Tourism Organisation (1997) 'Austrian Visitor Survey Summer 1997', available at www.cms.austriatourism.biz/, accessed 6th June, 2003.

(30) Bundesamt fuer Statistik (2002) 'Swiss Tourism in Figures', available at www. swisstourfed.ch/art/dokumente/vademekum/ de/IN_de.pdf, accessed 6th June, 2003.

(31) Carson and Waller, ref. 8 above.

(32) Ibid.

(33) Hall, C. M. and Page, S. J. (1999) 'The Geography of Tourism and Recreation', Routledge, London.

(34) Fesenmaier, D. R. (1994) 'Traveller use of visitor information centers: Implications for development in Illinois', Journal of Travel Research, Vol. 32, No. 1, pp. 44-50; Derrett, ref. 6 above; Scott, ref. 6 above.

(35) Carson and Waller, ref. 8 above.

(36) Carson et al., ref. 1 above. 